\title{
Morphometric variation in collared lemming (Rodentia, Arvicolinae, Dicrostonyx) in the Eurasian Arctic in relation to karyotype and mitochondrial DNA diversity
}

\author{
Nataliya I. Abramson \& Elena P. Tikhonova
}

\begin{abstract}
The degree of craniometric differences between the taxa, chromosome races and phylogeographic groups of the genus Dicrostonyx in the Palaearctic were accessed using discriminant function analysis. Contrary to results obtained by the previous authors it was shown that recognized taxa differ significantly in the structure of the skull and mandible. Individual characters and their combinations most suitable for the discrimination of species and subspecies have been revealed. Analysis of correlation between the chromosomal, molecular and morphological divergence in the collared lemming from the Palaearctic part of the range showed that there is consistency between morphological and molecular (mtDNA diversity) data and discrepancy between morphological and chromosomal data. Known models of chromosome speciation and phylogeographic hypotheses are discussed in the light of the data obtained.
\end{abstract}

KEY WORDS: Dicrostonyx, morphometric variation, chromosome races, mtDNA clades.

Nataliya I. Abramson [Nataliya@asv.mail.iephb.ru], Zoological Institute, Russian Academy of Sciences, Universitetskaya nab. 1, Saint Petersburg 199034, Russia; Elena P. Tikhonova, Zoological Institute, Russian Academy of Sciences, Universitetskaya nab. 1, Saint Petersburg 199034, Russia.

\section{Морфометрическая изменчивость копытного лемминга (Rodentia, Arvicolinae, Dicrostonyx) в Евразийской Арктике: соотношение с изменчивостью кариотипа и митохондриальной ДНК}

\section{Н.И. Абрамсон, Е.П. Тихонова}

\begin{abstract}
РЕЗЮМЕ. Методом канонического пошагового анализа исследована степень краниометрических различий между таксонами, хромосомными расами и филогеографическими группами родаDicrostonyx в Палеарктике. В отличие от результатов исследований предыдущих авторов показано, что описанные ранее таксоны достоверно различаются по строению черепа и нижней челюсти, выделены отдельные признаки и их сочетания, наиболее пригодные для характеристики подвидов и видов. Анализ соотношения между хромосомной, молекулярной и морфологической дивергенцией у копытного лемминга в Палеарктической части ареала показал наличие соответствия между уровнем морфологической и молекулярной (изменчивостью митохондриальной ДНК) дивергенцией и отсутствие соответствия между морфологической и хромосомной дивергенцией. На основании полученных результатов обсуждаются предложенные модели хромосомного формообразования и филогеографические гипотезы.
\end{abstract}

КЛЮЧЕВЫЕСЛОВА:Dicrostonyx, морфометрическая изменчивость, хромосомные расы, мтДНК клады.

\section{Introduction}

Collared lemmings (Dicrostonyx Gloger, 1841) and true lemmings (Lemmus Link, 1795) are the most mass rodents of the tundra and are almost sympatrically distributed over the major part of the Arctic. In contrast to the true lemmings, the collared lemmings display extremely high variability of karyotype (Gileva, 1983). Recent surveys revealed that there are at least five chromosome races in the Eurasian Arctic (Fredga et al., 1999) and up to eighth races in North America (Raush \& Raush, 1972). At the same time geographic variation of the pelage color and external characters is poorly pro- nounced and collared lemmings from different localities of the circumpolar range appeared to be so phenotypically similar that often only one or two Holarctic species are recognized within the genus: only $D$. torquatus (Pallas, 1779) (Ognev, 1948; Corbet, 1978), or $D$. torquatus in the Palaearctic and D. groenlandicus Traill, 1823 in the Nearctic (Hall, 1981). Collared lemming from Labrador Peninsula is often regarded as an independent species, D. hudsonius (Pallas, 1778). The latter can be distinguished from all other recent forms by the primitive molar pattern similar with that in the extinct Middle Pleistocene D. simplicior Fejfar, 1966. After cytogenetic studies and hybridological experiments it 
was suggested to consider D. torquatus as a Holarctic superspecies and the rank of the most cytologically studied subspecies in the Nearctic has been elevated to the species level (Corbet \& Hill, 1991; Musser \& Carleton, 1993). In result the taxonomy of the genus remain uncertain and the number of species ascribed to Dicrostonyx varies from one to eleven.

Cytogenetic and hybridological studies of the collared lemmings in the Palaearctic showed that lemmings from the Wrangel Island appeared to be karyologically very different from lemmings of the mainland populations and in hybridization experiments resorption of the fetus always took place (Chernyavskii \& Kozlovskii, 1980). Following these results lemmings from the Wrangel Island were distinguished as an independent species D. vinogradovi Ognev, 1948 (Chernyavskii \& Kozlovskii, 1980). It should be emphasized that unlike the case with the true lemmings from this island, the structure of the karyotype of the $D$. vinogradovi is similar to the collared lemmings from Alaska, and, possible, in hybridization with the latter they may give fertile hybrids (Jarrell \& Fredga, 1993). Basing on the similarity in the karyotype structure these authors consider $D$. vinogradovi together with other Nearctic forms as subspecies of D. groenlandicus.

Additional cytogenetic studies involving material from the new sites in the Palaearctic part of the generic range and the analysis of mitochondrial DNA diversity carried out recently (Fredga et al., 1999) showed the existence of four chromosomal races and five phylogeographic groups. The results of these studies, however, until now had no influence on the taxonomy of the genus.

It should be noted here that wide-ranging studies of geographic variation of cranial characters in Dicrostonyx based on the specimens involved in the karyological and molecular-genetic studies have not been carried out yet. It contributes greatly to retaining of taxonomic uncertainty in the composition of this genus. A number of papers devoted to the variation of cranial characters in Dicrostonyx in the Palaearctic was published by researchers from the Institute of Animal and Plant Ecology, Russian Academy of Sciences (Ekaterinburg) in 70-80-ies of the last century (Prushinskaya, 1978; Benenson \& Prushinskaya, 1979; Bol'shakov et al., 1980; Gileva et al., 1980; Prushinskaya et al., 1984). However, material used in these works was represented by colonies of laboratory animals derived from a small number of founders sampled in only two sites within the vast range of the genus.

The objective of this study is to evaluate the differences in cranial morphology between the chromosomal races, mitochondrial DNA clades, and taxonomic units of collared lemming in the Palaearctic using multivariate analysis. We also attempt to answer the two following questions:

Table 1. Arrangement of collared lemming (Dicrostonyx torquatus) Samples used for morphometric STUdY (SEE ALSO FIG. 1).

\begin{tabular}{|c|c|c|c|c|c|c|c|}
\hline Taxon & $\mathrm{n}$ & Samples & $\mathrm{n}$ & Chromosomal races & $\mathrm{n}$ & Mitochondrial clades & $\mathrm{n}$ \\
\hline \multirow{4}{*}{ D. t. torquatus } & \multirow{4}{*}{74} & $\begin{array}{l}\text { Malozemel'skaya Tundra, Timanskaya } \\
\text { Tundra, Vorkuta area }\end{array}$ & 18 & I & 83 & $A$ & 23 \\
\hline & & Polarnyi Ural & 5 & & & & \\
\hline & & Yamal Peninsula & 41 & & & B & 57 \\
\hline & & Gydan Peninsula & 16 & & & & \\
\hline \multirow{10}{*}{$\begin{array}{l}\text { D. } t . \\
\text { chionopaes }\end{array}$} & \multirow{10}{*}{146} & North-Western Taimyr & 18 & & & $\mathrm{C}$ & 65 \\
\hline & & Central Taimyr & 28 & ॥ & 95 & & \\
\hline & & North-Eastern Taimyr & 19 & & & & \\
\hline & & Khatanga-Lena Interfluvial & 14 & & & $\mathrm{D}$ & 40 \\
\hline & & Lena delta & 13 & & & & \\
\hline & & Yana delta & 7 & III & 13 & & \\
\hline & & Indigirka delta & 2 & & & & \\
\hline & & Kolyma delta, left bank & 4 & & & & \\
\hline & & Kolyma delta, right bank & 3 & IV & 29 & $E$ & 29 \\
\hline & & Chukotka Peninsula & 26 & & & & \\
\hline D. t. ungulatus & 35 & Novaya Zemlya & 35 & no data & 35 & no data & 35 \\
\hline D. vinogradovi & 28 & Wrangel Island & 28 & V & 28 & $\mathrm{~F}$ & 28 \\
\hline
\end{tabular}

$\mathrm{n}$ - sample size. 


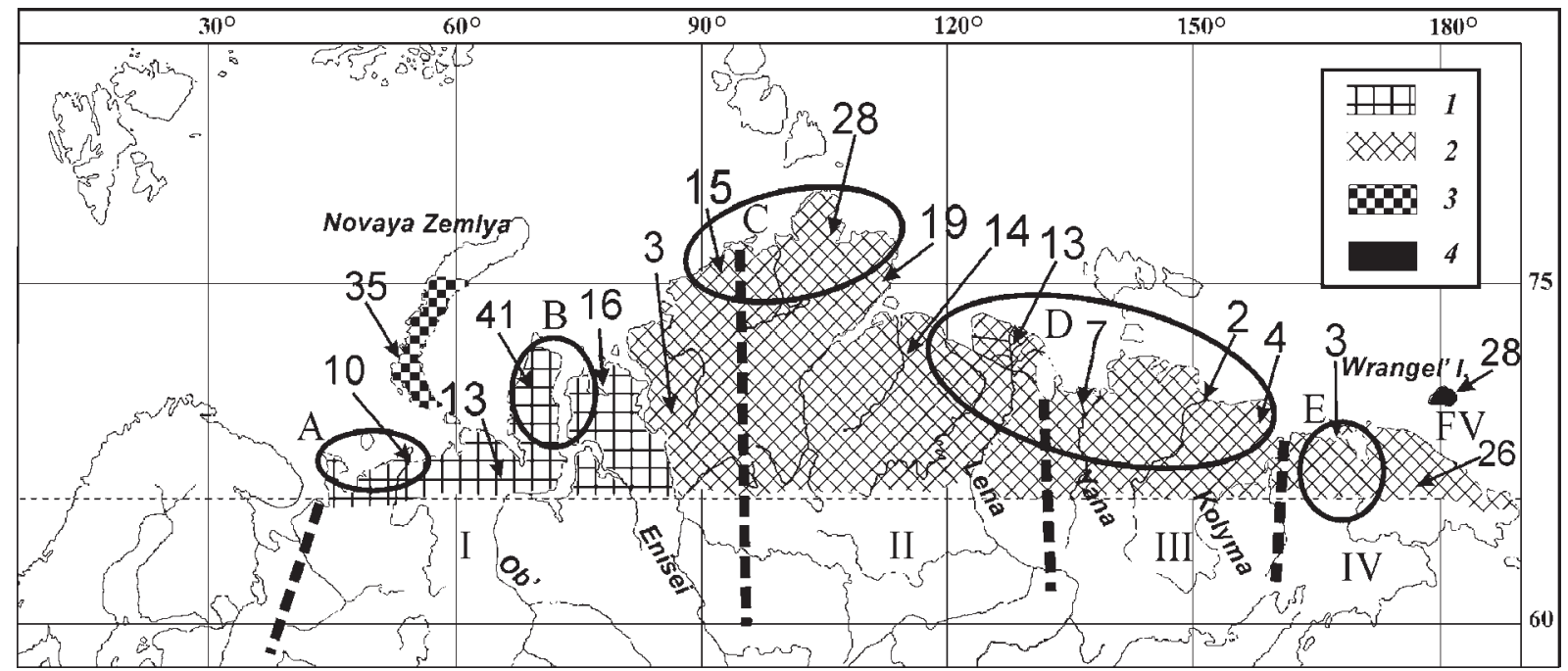

Figure 1. Map of distribution range ofDicrostonyx taxa, chromosome races and mitochondrial clades (after Fredgaet al., 1999). $1-$ D. t. torquatus; $2-$ D. t. chionopaes; $3-$ D. t. ungulatus; $4-$ D. vinogradovi. Approximate borders between chromosome races (IIV) are shown by dotted lines, approximate ranges of mitochondrial clades (A-F) by solid lines, arrows show sample localities, numbers at the arrows indicate sample size.

1) Are the karyotypic races, mitochondrial DNA clades, and presently recognized subspecies morphometrically recognizable with a sufficient confidence?

2) Is there any pattern of morphological differentiation that may be interpreted in the light of established models of chromosomal speciation and phylogeographic hypotheses?

\section{Material and methods}

A total of 296 Dicrostonyx skulls were measured from the collections of the Zoological Institute, Russian Academy of Sciences (St.-Petersburg), Zoological Museum of Moscow State University (Moscow), and personal collection of V.N. Kalyakin (Faculty of Geography, Moscow State University, Moscow) from the archipelago Novaya Zemlya. The data on the geographic localities and the size of the samples studied are given in Tab. 1 and Fig. 1.

Material on collared lemming from the archipelago Novaya Zemlya comes from the content of owl pellets and contains numerous mandibles and few intact skulls. Due to this we performed morphometric analysis separately for the skulls and mandibles.

For each adult specimen the following cranial measurements were taken to the nearest $0.1 \mathrm{~mm}$ using dial calipers: $\mathrm{CBL}$ - condylobasal length, the distance from the condyles to the junction of premaxillary bones; BRAINL - the length of the braincase, the distance from the anterior border of the postorbital ridge to the condyles; NASL - the length of the nasal bones; LMASSALV - the distance from the point of attachment of $\mathrm{m}$. masseter superfacialis to the anterior edge of M1; LDIASTUP - the length of the upper diastema; LM1M3 - length of the maxillary tooth row (M1-M3), the distance from the posterior edge of the third molar to the anterior border of the alveolus of the first molar; LINCF - the length of the incisive foramen; LPALATE - length of palate, distance from the posterior edge of the alveolus of the inner incisor to the posterior margin of the palate; HSKULL - height of the skull, distance from basisphenoid- basioccipital suture to interparietal-parietal suture; W-1 - width of the skull taken immediately before auditory bullae; W-2 - width of the skull posterior to postorbital processes; ZYGW zygomatic width of the skull; INTERORB - interorbital width of the skull, minimal interorbital distance across the frontals; WROSTR - the greatest width of rostrum measured at the premaxillae immediately below the anterior extremities of the nasals; MINMOL - the minimal distance between the tooth rows; MAXMOL - the greatest distance between the tooth rows; LMAND - length of the mandible, the distance from the angular process to the anterior border of the incisor alveolus; LCONALIN - the distance from the tip of the condylar processes of mandible to the anterior border of the incisor alveolus; LDIAST - length of the mandible diastema; Lm1-m3 - length of the mandible tooth row, the distance from the posterior edge of the third molar to the anterior border of the alveolus of the first molar; HMAND — height of mandible, the distance from the condylar processes to the base of the mandible; HSYMPH - the depth of the mandible at the symphysis.

Sexual dimorphism was assessed with ANOVA, using one-way design of males against females where samples were sufficiently large $(n>15)$. The results have shown that there are no statistically significant differences between sexes, so the subsequent analyses used the samples with the sexes combined.

In correspondence with the objectives of the study material was grouped according to belonging either to 1) taxonomic unit, 2) chromosomal race (after Fredga et al., 1999), and 3 ) phylogeographic group, distinguished on the base of $\mathrm{mtD}$ NA diversity (after Fredga et al., 1999) (see Tab. 1).

The samples of collared lemming grouped in this way were then compared using the stepwise discriminant function analysis. All calculations were performed using software Statistica for Windows, version 5.5.

The contribution of individual characters into the differences between the distinguished groups was assessed with ANOVA using one-way design. 
TABLE 2. First tWo StANDARDIZED VECTORS FROM tHE DISCRIMINANT FUNCTION ANALYSIS OF FOUR MANDIBLE VARIABLES FROM DICROSTONYX TAXA.

\begin{tabular}{|l|c|c|}
\hline \multirow{2}{*}{ Variable } & \multicolumn{2}{|c|}{ Standard ized canonical vectors } \\
\cline { 2 - 3 } & 1 & 2 \\
\hline LMAND_2 & -1.3111 & 0.848602 \\
\hline HSYMPH & -0.73576 & -0.49332 \\
\hline HMAND & 0.052676 & -0.01701 \\
\hline LCONALIN & 0.964192 & -0.79154 \\
\hline Eigenvalue & 0.299514 & 0.234511 \\
\hline Cumulative percent & 48.03 & 0.856533 \\
\hline
\end{tabular}

\section{Results}

\section{The differences between taxonomic units}

As was noted above, two species, D. torquatus and D. vinogradovi are distinguished in the Palaearctic part of the Dicrostonyx range on the base of karyological differences and hybridization experiments. Within $D$. torquatus, in its turn, three subspecies are distinguished on the base of some differences in the pelage color. Two subspecies are inhabiting the mainland tundra: $D$. $t$. torquatus Pallas, 1779 (European part of Russia up to Taimyr Peninsula) and D. t. chionopaes Allen, 1914 (from Taimyr Peninsula up to Chukotka Peninsula). $D$. t. ungulatus (Baer, 1841) is inhabiting the archipelago Novaya Zemlya.

The results of the multiple discriminant function analysis of the subsamples of taxa listed above carried on variables of mandible are presented in Tab. 2 and Fig. 2. The graph (Fig. 2) shows the centroid of each group

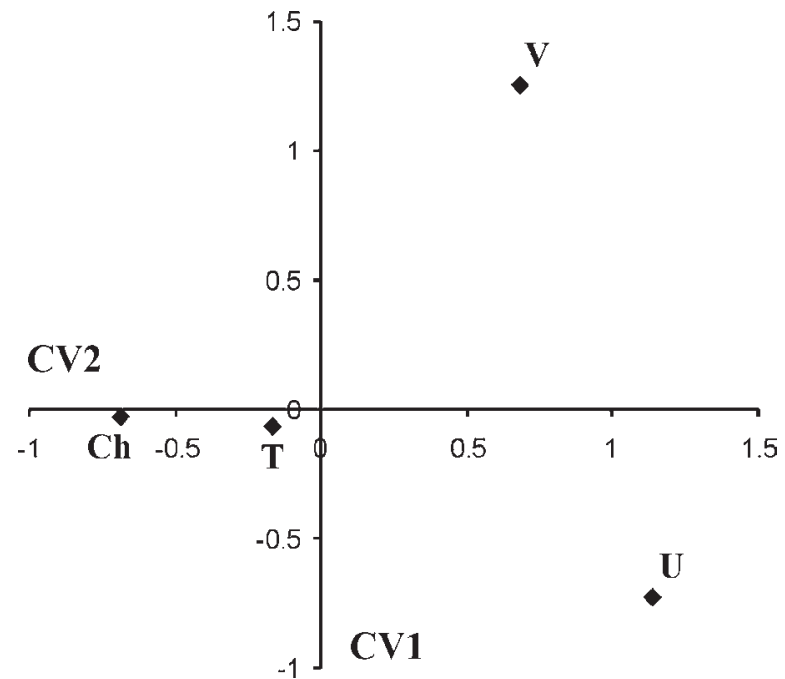

Figure 2. Projections of the centroids of the pooled samples of Dicrostonyx taxa onto the first two canonical axes. Analysis performed on the characters of mandible.

$\mathrm{T}-$ D. t. torquatus; $\mathrm{Ch}-$ D. t. chionopaes $; \mathrm{U}-$ D. t. ungulatus; $\mathrm{V}-$ D. vinogradovi.

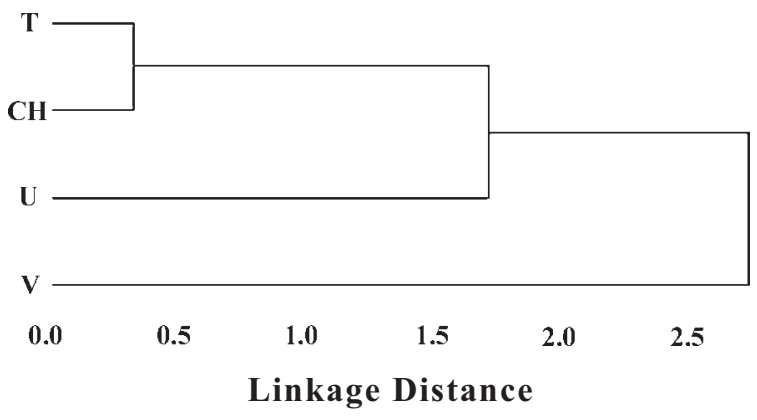

Figure 3. Distance phenogram summarizing the morphometric relationships of Palaearctic taxa of Dicrostonyx based on the mandible characters. UPGMA cluster analysis of the matrix of generalized distances.

plotted onto the first two canonical axes. The first and the second canonical axes explain a little over $83 \%$ of the mandible variation. HSYMPH and LCONALIN contribute to a considerable extent to discrimination on the first axis. On the second axis LMAND contributes to discrimination to an important degree. The differences between centroids of the groups are highly significant $(p<0.0001)$. The results of the UPGMA cluster analysis of the matrix of Generalized Distances among the taxa considered are shown in the form of a phenogram (Fig. 3 ). By the structure of mandible $D$. vinogradovi differs from all other forms most considerably. Among subspecies of $D$. torquatus the differences between the island D. t. ungulatus and the mainland D. t. torquatus and $D$. $t$. chionopaes are much more pronounced than between the mainland subspecies (Fig. 3).D. vinogradovi differs by the greatest size of the mandible and height of condylar processes. D. t. ungulatus differs by the smallest size of the mandible.

Results of the analogous analysis performed on the cranial variables are shown in the Fig. 4A. The first two canonical axes explain a little over $97.4 \%$ of the intergroup variance $(75 \%$ and $22,4 \%$ respectively). The variables W-1, INTEROB, NASL, HSKULL contribute to discrimination of samples most significantly (Tab. 3). The differences between group centroids are highly significant both in analysis of absolute values and in analysis of indices (except difference between $D$. $t$. torquatus and D. t. ungulatus). The bivariate plot of centroids show (Fig. 4A) the clear ordination of samples studied into two groups: $D$. vinogradovion the one hand and all the other samples (representing the subspecies of $D$. torquatus) on the other. D. vinogradovi differs from $D$. torquatus by wider skull in the auditory bullae region (W-1), narrower interorbital region, and narrower zygomatic arches.

Highly pronounced cranial differences between two species $D$. vinogradovi and $D$. torquatus obscure the differences between subspecies within the latter. In order to evaluate the differences in the cranial morphology of subspecies of $D$. torquatus we performed a new analysis of all samples except collared lemmings from the Wrangel Island. With the new set of samples the 
TABLE 3. FiRst tWo STANDARDIZED VECTORS FROM THE DISCRIMINANT FUNCTION ANALYSIS OF CRANIAL VARIABLES OF DICROSTONYX TAXA.

\begin{tabular}{|l|c|c|c|}
\hline \multirow{2}{*}{ Variable } & \multicolumn{3}{|c|}{ Standardized canonical vectors } \\
\cline { 2 - 4 } & 1 & 2 & 3 \\
\hline W_1 & -0.55921 & -0.16814 & 0.283204 \\
\hline INTEROB & 0.519105 & 0.30405 & -0.10701 \\
\hline NASL & 0.511908 & -0.16685 & 0.362267 \\
\hline HSKULL & -0.36475 & 0.558211 & -0.45705 \\
\hline MINMOL & -0.09489 & -0.65967 & -0.23455 \\
\hline BRAINL & -0.22206 & -0.64957 & -0.55503 \\
\hline ZYGW & 0.67166 & 0.131619 & -0.52857 \\
\hline LDIAST & -0.42401 & 0.061011 & 0.961306 \\
\hline LM1-M3 & -0.07613 & 0.366884 & -0.17952 \\
\hline W_2 & -0.2608 & 0.07113 & 0.015957 \\
\hline WROSTR & 0.186391 & -0.03966 & 0.191566 \\
\hline Eigenvalue & 0.512137 & 0.152338 & 0.017702 \\
\hline $\begin{array}{l}\text { Cumulative } \\
\text { percent }\end{array}$ & 0.750739 & 0.974051 & 1 \\
\hline
\end{tabular}
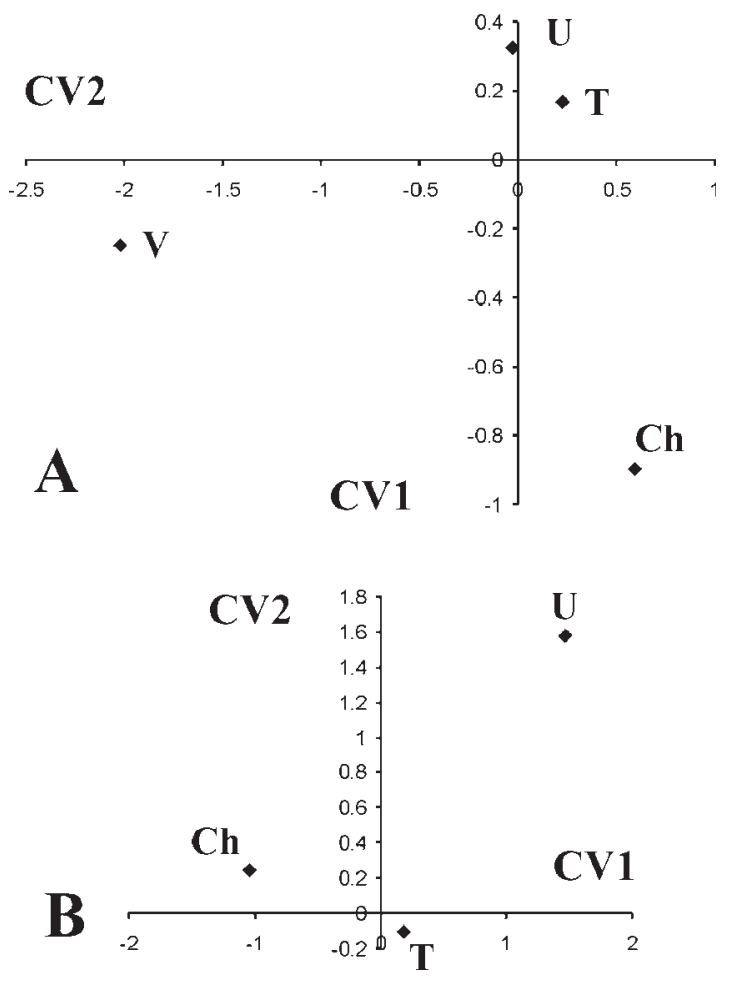

Figure 4. Projections of the centroids of the pooled samples of Dicrostonyx taxa onto the first two canonical axes. Designations of taxa as on Fig. 2.

A - Analysis performed on the cranial characters; B - The same analysis carried on with the subspecies of Dicrostonyx torquatus.

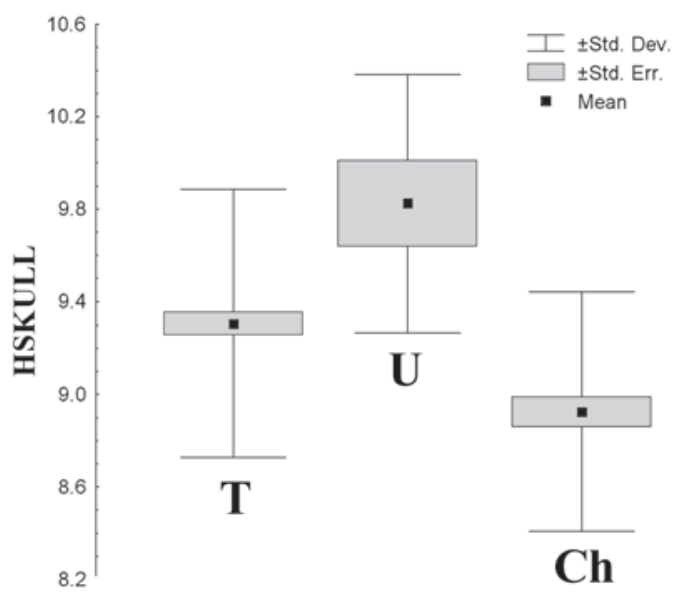

Figure 5. The differences in the height of the skull between subspecies of Dicrostonyx torquatus. Designations of taxa as on Fig. 2.

Std. Dev. - Standard deviation; Std. Err. - Standard error.

cranial differences between subspecies appeared to be significantly higher, the distances between centroids of all samples are highly significant. Therewith, D. t. ungulatus not only significantly differs from $D$. t. torquatus and $D$. $t$. chionopaes, but the difference between the collared lemmings from the archipelago Novaya Zemlya and each of the mainland subspecies significantly exceeds the difference between mainland subspecies (Fig. 4B). The greatest contribution into discrimination of samples in this case belongs to the HSKULL, NASL, BRAINL.D. t. ungulatus differs from other forms by the largest height of the skull (Fig. 5) and smallest length of the nasals.

Analysis of morphometric differences between the chromosomal races

Within the Palaearctic range of the collared lemmings five chromosomal races (Tab. 1, Fig. 1) were distinguished based on the structure and chromosome sets (Fredga et al., 1999). If distribution of these races is compared with the distribution of the taxa considered above, it becomes clear that D. t. torquatus is represented only by the race I, and $D$. $t$. chionopaes by races I-IV. D. vinogradovi differs considerably in the structure of karyotype from all other Palaearctic races and designated here as the race $\mathrm{V}$. The karyotype of $D$. t. ungulatus is unknown. Analysis of morphometric differences between the chromosomal races both by cranial and mandible characters confirmed the data obtained earlier in the analysis of taxonomic groups in the case when the borders of taxon and chromosomal race coincide. Thus, the chromosome race $\mathrm{V}$ considerably differs from all other races, and significant differences are marked between the races I and II. Just the border between these races almost coincides with the border of two mainland subspecies. No difference was found between the races II and III and races I and IV. The projection of the centroids of the 


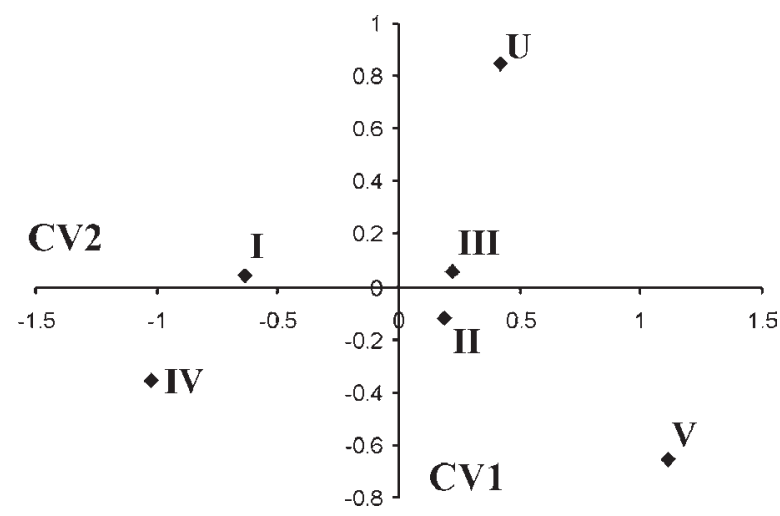

Figure 6. Projections of the centroids of chromosome races samples onto two first canonical axes. Designations of races as on the Fig. 1 and taxa as on Fig. 2.

samples considered onto the first two canonical axes is shown in the Fig. 6. Lemmings from the archipelago Novaya Zemlya that are not studied karyologically morphometrically differ from all known chromosomal races, but appeared to be most close to races II and III.

\section{Morphometric differences between phylo- geographic groups}

Five phylogeographic groups distinguished on the base of the mtDNA diversity correspond to the taxonomic structure of the genus and chromosome races in the following way: D. t. torquatus is represented by two phylogeographic clades (A and B) and chromosome race $\mathrm{I} ; D$. $t$. chionopaes is represented by three phylogeographic clades $(\mathrm{C}, \mathrm{D}$, and $\mathrm{E})$ and by three chromosome races (see above). However, there is no correspondence between chromosome races and phylogeographic clades. The clade $\mathrm{C}$ is partly overlapping the chromosome races I and II, the clade D overlaps the chromosome races II and III, and only the clade E corresponds to the chromosome race IV. Like in the case with karyotype, the difference in mtDNA diversity between $D$. vinogradovi and all other forms is so significant that Fredga et al. (1999) refused to consider it together with other Palaearctic forms. Here we designated this clade as $\mathrm{F}$ (chromosome race $\mathrm{V}$ ).

Unlike the chromosomal races, discriminant function analysis performed on cranial and mandibular characters showed that the differences between the centroids of samples from all phylogeographic clades are significant $(\mathrm{p}<0.0001 ;$ Fig. 7$)$.

\section{Discussion}

Analysis of morphometric differences between the forms distinguished within the genus Dicrostonyx in the Palaearctic showed a good consistency between the level of divergence both in the structure of the skull and mandible and recognized taxonomic structure. Therewith, the level of morphological divergence of the sub-

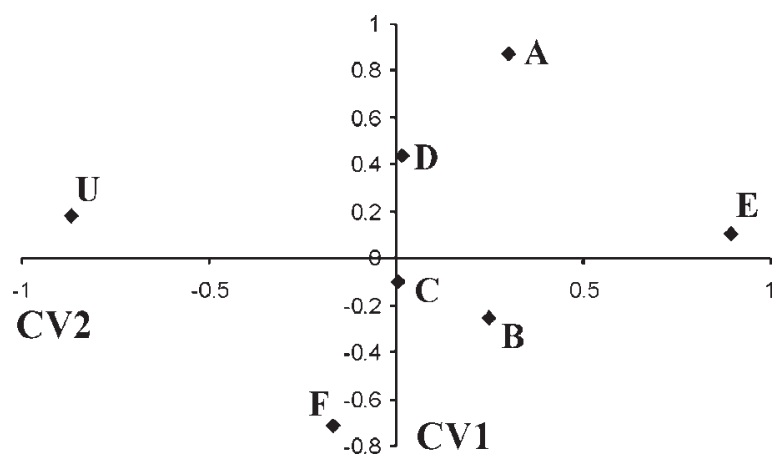

Figure 7. Projections of the centroids of mitochondrial DNA clades samples two first canonical axes. Designations of races as on the Fig. 1 and taxa as on Fig. 2.

species from the archipelago Novaya Zemlya (D. $t$. ungulatus) considerably exceeds the level observed between two mainland subspecies. In previous studies (Chernyavskii, 1972; Prushinskaya et al., 1984) stability of cranial characters inDicrostonyx within the whole Palaearctic range was emphasized. The diagnostics of subspecies was based exclusively on the details of the pelage color (Gromov \& Erbaeva, 1995). However, multivariate analysis of cranial characters revealed both individual characters and their combinations which discriminate the taxa rather reliably.

Analysis of morphological differences between five phylogeographic groups, distinguished on the base of mtDNA diversity, showed significant differences between all groups. It is interesting to note that the differences between chromosomal races which occur at the same territory are poorly pronounced or have a random character. Discrepancy in morphological and chromosomal variation has been observed earlier for other species that display chromosome polymorphism (Wojcik et al., 2000).

How the morphometric data presented here correspond to known models of chromosome speciation and phylogeographic hypothesis? Up to now there are two hypothesis most popular for explaining the chromosome variation and the pattern of speciation in collared lemming. According to the first one (hypothesis of refugiums by Macpherson, 1965) differentiation onto the chromosome races occurred in the Late Pleistocene during the fragmentation of the range by ice sheets and following isolation of populations in individual refugiums. If this hypothesis to be true then the geographic patterns of chromosome and mtDNA variation should coincide. According to the second hypothesis (sympatric chromosome speciation - stasipatric model of White $1968,1978)$ the pattern of geographic distribution of cromosomal races and mtDNA clades may be different. Two independent studies carried on Dicrostonyx (Engstrom et al., 1993; Fedorov et al., 1999) showed that there are no any substantial correspondence between chromosome races and mtDNA clades, and the second model of chromosome race origin is more appropriate. 
Our data on cranial and mandibular morphology also favor the second hypothesis. Similar results and conclusions have been obtained in the study of morphological and chromosomal variation in Sorex araneus (Wojciket al.,2000). Differentiation on the phylogeographic clades inferred from mtDNA diversity by general opinion is determined by past events such as ice ages, which cause populations, genomes and species to contract and expand their ranges enormously (Hewitt, 1989, 1996; Avise, 1994). It becomes well established that Pleistocene glacial cycles had a great influence on the population genetic differentiation and speciation. Consistency between morphological and mtDNA variation then seems to be logical.

\section{Conclusions}

The previous studies of craniometric variation in Dicrostonyx (e.g., Chernyavskii, 1972; Prushinskaya et al., 1984) considered variation of individual characters and did not take in account their interrelation. It led to underestimation of craniometric differences in characterization of taxa. The multivariate approach allowed us to reveal significant differences in the structure of the skull and mandible, to underline individual characters and their combination that are most suitable for the characteristics of species and subspecies. Analysis of correlation between the chromosomal, molecular and morphological variation in collared lemming in the Palaearctic part of the range showed a rather good consistency between morphological and mtDNA variation and the lack of consistency between the morphological and chromosomal variation.

What influence may have the data obtained on the generally recognized taxonomic structure of the genus in the Palaearctic? The results of the study show that morphological differentiation of collared lemmings has it adequate reflection in the taxonomic scheme adopted today.

ACKNOWLEDGEMENTS. We thank Dr. I.Ya. Pavlinov (Zoological Museum, Moscow State University) for the assistance while working in the collections of the museum, Dr. V.N. Kalyakin (Geographical Faculty, Moscow State University) for the material supplied on collared lemmings from the archipelago Novaya Zemlya, valuable comments and discussion. We are grateful to Dr. M.V. Zaitsev (Zoological Institute RAS, St.-Petersburg) for critical comments on the manuscript and valuable discussion. The work was supported by the Russian Foundation for Basic Research, project N 00-0448849.

\section{References}

Avise J.C. 1994. Molecular Markers, Natural History and Evolution. New York: Chapman \& Hall. 511 p.

Benenson I.E. \& Prushinskaya N.M. 1979. [Population analysis of cranial variation in collared lemming using methods of multivariate statistics] // Problemy Ekologii Pribaikal'ya. T.4. P.16-17 [in Russian].
Bol'shakov V.N., Benenson I.E. \& Gileva E.A. 1980. [Cranial variation in two subspecies of collared lemming $\mathrm{Di}$ crostonyx torquatus Pall., 1779] // Dobrinskii L.N. \& Vigorov Yu.L. (ed.). [Inter- and Intrapopulation Variation of Mammals of Urals]. Sverdlovsk: Ural'skii Nauchnyi Tsentr, Institut Ekologii Rastenii i Zhivotnykh AN SSSR. P.18-36 [in Russian].

Chernyavskii F.B. 1972. [On the character of geographic variation in some mammal species of the North-Eastern Siberia (the clinal variation and subspecies concept)] // Zhurnal Obshchei Biologii. T.33. No.4. P.437-448 [in Russian with English summary].

Chernyavskii F.B. \& Kozlovskii À.I. 1980. [The species status and the history of collared lemmings (Dicrostonyx, Rodentia) of the Wrangel Island] // Zoologicheskii Zhurnal. T.59. No.2. P.266-273 [in Russian with English summary].

Corbet G.B. 1978. The Mammals of the Palaearctic Region: A Taxonomic Review. London, Ithaca: Cornell University Press. 314 p.

Corbet G.B. \& Hill J.E. 1991. A World List of Mammalian Species. London: Oxford University Press (Third Edition). $243 \mathrm{p}$.

Engstrom M.D., Baker A.J., Eger J.L., Boonstra R. \& Brooks R.J. 1993. Chromosomal and mitochondrial DNA variation in four laboratory populations of collared lemmings (Dicrostonyx) // Canadian Journal of Zoology. Vol.71. No.1. P.42-48.

Fedorov V.B., Fredga K. \& Jarell G.H. 1999. Mitochondrial DNA variation and the evolutionary history of chromosome races of collared lemmings (Dicrostonyx) in the Eurasian Arctic// Journal of Evolutionary Biology. Vol.12. No.1. P.134-145.

Fredga K., Fedorov V.B. \& Jarell G.H. 1999. Genetic diversity in arctic lemmings // Ambio. Vol.28. No.3. P.261-269.

Gileva E.A. 1983. A contrasted pattern of chromosome evolution in two genera of lemmings, Lemmus and Dicrostonyx (Mammalia, Rodentia) // Genetica. Vol.60. P.173-179.

Gileva E.A., Benenson I.E, Bol'shakov V.N. \& Prushinskaya, N.M. 1980. [To the integral evaluation of inter- and intrapopulational variation of craniometric characters in rodents] // Pesenko Yu.A. (ed.). [Quantitative Methods in Animals Ecology]. Leningrad: Zoologicheskii Institut AN SSSR. P.45-47 [in Russian].

Gromov I.M. \& Erbaeva M.A. 1995. [The Mammals of Russia and Adjacent Territories. Lagomorphs and Rodents]. Sankt-Peterburg: Zoologicheskii Institut RAN. 522 p. [in Russian].

Hall E.R. 1981 The Mammals of North America. New York, Chichester, Brisbane, Toronto: John Wiley and sons (Second Edition). 600 p.

Hewitt G.M. 1989. The subdivision of species by hybrid zones // Otte D. \& Endler J. (eds.). Speciation and its Consequences. Sunderland (Mass.): Sinauer Associates. P.85-110.

Hewitt G.M. 1996. Some genetic consequences of ice ages and their role in divergence and speciation // Biological Journal of the Linnean Society. Vol.58. No.3. P.247-276.

Jarrell G.H. \& Fredga K. 1993. How many kinds of lemmings? A taxonomic overview // Stenseth N.C. \& Ims R.A. (eds.). The Biology of Lemmings. London: Academ- 
ic Press. P.45-57.

Macpherson A..H. 1965. The origin of diversity in mammals of the Canadian Arctic tundra // Systematic Zoology. Vol.14. No.2. P.153-173.

Musser G.G. \& Carleton M.D. 1993. Family Muridae// Wilson D.E. \& Reeder D.M. (eds.). Mammal Species of the World: A Taxonomic and Geographic Reference. Washington, London: Smithsonian Institution Press. P.501-755.

Ognev S.I. 1948. [Mammals of the USSR and Adjacent Countries]. T.6. Moskva-Leningrad: Izdatel'stvo AN SSSR. 559 p. [in Russian].

Prushinskaya N.M. 1978. [The variation of size and proportions of the skull in the collared lemming] // Vigorov Yu.L. (ed.). [Fauna, Ecology, and Variation of Animals]. Sverdlovsk: Ural'skii Nauchnyi Tsentr, Institut Ekologii Rastenii i Zhivotnykh AN SSSR. P.18-21 [in Russian].

Prushinskaya N.M., Bol'shakov V.N. \& Gileva E.A. 1984.
[The variation of correlation structure in the skull of the collared lemming] // Dobrinskii L.N. (ed.). [Population Ecology and Morphology of Mammals]. Sverdlovsk: Ural'skii Nauchnyi Tsentr, Institut Ekologii Rastenii i Zhivotnykh AN SSSR. P.37-52 [in Russian].

Raush R.R. \& Raush V.R. 1972. Observation on chromosomes of Dicrostonyx torquatus stevensoni Nelson and chromosomal diversity in varying lemmings // Zeitschrift für Säugetierkunde. Bd.37. Hf.6. P.372-384.

White M.J.D. 1968. Models of speciation // Science. Vol.159. No.3819. P.1065-1070.

White M.J.D. 1978. Chain processes in chromosomal speciation // Systematic Zoology. Vol.27. No.3. P.285-298.

Wojcik J.M., Bogdanowicz W., Pucek Z., Wojcik A.M. \& Zalewska H. 2000. Morphometric variation of the common shrew Sorex araneus in Poland, in relation to karyotype // Acta Theriologica. Vol.45. Supplement 1. P.161-172. 